\title{
SAWDUST AS A FILLER TO ALKALI-ACTIVATED FLY-ASH
}

\author{
HALAS, O[lena]; BENES, L[ibor] \& MINAR, L[ubos]
}

\begin{abstract}
: this article describes a relatively new type of materials - alkali-activated materials, the process of their formation and princip of alkaline activation, possible raw materials (primary and secondary), advantages and perspectives of alkali-activated material's further research. The experimental part of this article shows the results of alkaliactivated materials study based on fly-ash with the adding of woodworking waste material - sawdust (strength comparison of samples with different amount of sawdust).
\end{abstract}

Key words: alkali-activated materials, alkaline activation, aluminosilicates, fly-ash

\section{INTRODUCTION}

The principle of alkaline activation process was discovered in the first half of the 20th century (Olsen, 1934; Davidovits, 2008; Glukhovsky, 1959). In this process can be used any kind of material with aluminosilicate content, even waste materials such as fly ash, slag. Alkali activation is the process of aluminosilicates dissolution in strongly alkaline solution, with a subsequent formation of aluminosilicate networks composed of $\mathrm{AlO}_{4}$ and $\mathrm{SiO}_{4}$ tetrahedrons. The result of the alkaline activation is a new kind of material similar to some minerals. The main benefit of this discovery is reduction of irreplaceable natural resources consumption. Another benefit is utilization of such energy industry waste materials as ashes and slags which woud have a positive affect on environment. Alkali activated materials can be also used for preparing of composites for friction components. However these properties must be tested on measuring equipment (Barborak et al., 2008; Bozek, 2008, 2009).

The raising environmental awareness conduces to the more significant development of alternative materials in the construction industry. The main aim of the alkaline activated materials' deeper research is to reduce exploitation of scarce natural resources and find application for increasing amount of waste materials. The major development in the field of these material intensifies mainly in the last few decades, but the first work in this area can be traced at the beginning of the last century (Purdon, 1940; Feret, 1939;), this information is taken from (Davidovits, 2008).

There is still no general terminology in this field of research. It is due to the absence of standards, which would stipulate the conditions of usage and basic methodological approaches for working with these materials and facilitate their distribution. Instead of this, there are often used the standards for concrete, even though we had proved the amorphous nature of these new materials. The structure of cement concrete has a polycrystalline nature - that's why the application of standards for concrete in the case of alkali-activated materials is preposterous. It is also possible, as shown by the authors of the aforementioned article (Srtaka et al., 2001), to adopt some of the current standards, mainly for determining the mechanical and physical properties (density, water absorption, compressive strength, flexural strength, modulus, specific heat coefficient, heat capacity etc.). Another standards is then necessary to create completely from the beginning. New standards would apply to the thermal resistance, frost resistance and other properties.

\subsection{Raw materials}

Basic materials for geopolymeric reaction can be divided into two groups - in the first group there are materials of natural origin (kaolinitic clays, metakaolin) and in the second group there are artificial materials (blast furnace slag, fly ash).

\subsection{Fly ash - production and alkaline activation}

One of the first studies of alkali activated fly ash concerned the synthesis of zeolites. This synthesis was introduced by Holler in the 80th years of 20th century (Holler, 1983). The zeolit was synthetized by alkaline activation of fly ash in $\mathrm{NaOH}$ and $\mathrm{KOH}$ solutions in hydrothermal conditions.

Presently, the production of solid waste materials in burning processes of power and heat stations in Czech Republic exceeds ten million tons annually (analysis of the year 2003). CEZ power energy company produces about 10 million ton of this waste every single year.The fly ash produced by power stations is a suitable raw material for alkali-activated materials thanks to its high content of silicon and aluminium oxides. These materials are generated by solving of aluminium-silicates (kaolin, clays, metallurgy and energy industries waste products, and others), and by subsequent transformation into threedimensional nets. The solving process is initiated by a highly alkaline environment with $\mathrm{pH} 12$ - 14. It can be stated that these materials are the result of reactions of aluminium-silicate substances in the highly alkaline environment. Despite of huge diversity and cheapness of secondary products (fly ash, slag, ceramic or metallurgy industries waste) it is also studied primary raw materials for producing of alkali-activated materials (Skvara, 2009; Pacheco-Torgal, 2005; Benes et al., 2007; Palomo et al., 1999; van Jaarsveld et al., 2002).

In the previous studies, the influence of main components of the mixture has been described (amount of $\mathrm{Na}_{2} \mathrm{O}, \mathrm{H}_{2} \mathrm{O}$ alkali activator and fly ash). There can be used many kinds of materials as additives to the alkali-activated mixture. One of the possibilities is to use sawdust from woodworking. The sawdust amount could have a significant influence on the strength of the material. This study can allow us to evaluate this influence. There is an influence of sawdust on the compressive strength of the alkali-activated material based on fly-ash.

\begin{tabular}{|l|l|l|l|l|l|l|l|l|l|l|l|}
\hline & $\begin{array}{l}\mathbf{S i} \\
{[\%]}\end{array}$ & $\begin{array}{l}\mathbf{A l} \\
{[\%]}\end{array}$ & $\begin{array}{l}\mathbf{N a} \\
{[\%]}\end{array}$ & $\begin{array}{l}\mathbf{K} \\
{[\%]}\end{array}$ & $\begin{array}{l}\mathbf{C a} \\
{[\%]}\end{array}$ & $\begin{array}{l}\mathbf{M g} \\
{[\%]}\end{array}$ & $\begin{array}{l}\mathbf{F e} \\
{[\%]}\end{array}$ & $\begin{array}{l}\mathbf{T i} \\
{[\%]}\end{array}$ & $\begin{array}{l}\mathbf{O} \\
{[\%]}\end{array}$ & $\begin{array}{l}\text { Suma } \\
{[\%]}\end{array}$ & $\mathbf{S i} / \mathbf{A l}$ \\
\hline Opatovice & 20,57 & 13,59 & 0,27 & 1,91 & 0,88 & 0,54 & 3,49 & 0,7 & 58,06 & 99,99 & 1,51 \\
\hline
\end{tabular}

Tab. 1. Chemical composition of the fly ash 


\section{ALKALI-ACTIVATED MATERIALS BASED ON FLY-ASH WITH A SAWDUST ADDITION}

\subsection{Materials}

For this study, the fly ash from Opatovice electric power station (Czech Republic) was used. Its chemical composition is shown in the Table 1.

As the alkali activator, there were used two components: the pellet-form $\mathrm{NaOH}$ ( $98 \%$ purity) and the sodium silicate, which had the next composition comprising: $8 \%$ of $\mathrm{Na}_{2} \mathrm{O}$, $26,5 \%$ of $\mathrm{Si}_{2} \mathrm{O}, 65,5 \%$ of $\mathrm{H} 2 \mathrm{O}$.

\subsection{Method}

There was prepared five series of samples with different amount of tiny sawdust. Defined quantity of fly ash was replaced with commensurable quantity of sawdust. This amount varied from 5 till $25 \%$. The sawdust was put to the prepared geopolymer mixture (fly ash + water glass + sodium hydroxide). After blending the mixture, the samples were formed into silicone molds. The heat treatment of the samples was provided in two steps. Firstly, the formed pieces were put into the stove for 18 hours under the temperature $60^{\circ} \mathrm{C}$. Than the next day, the samples were unmolded and put again into the stove for 18 hours under the temperature $60{ }^{\circ} \mathrm{C}$. The samples had the form of cube with dimensions $3 \mathrm{~cm} \times 3 \mathrm{~cm} \times 3 \mathrm{~cm}$.

After the heat treatment till testing the samples were left in normal laboratory conditions. The pieces were tested on compressive strength in 28 days after sampling. The tests were conducting on testing mashine ZD 10190. It detected the maximum measured force for each sample. The results of the test are shown in the figure 1 below:

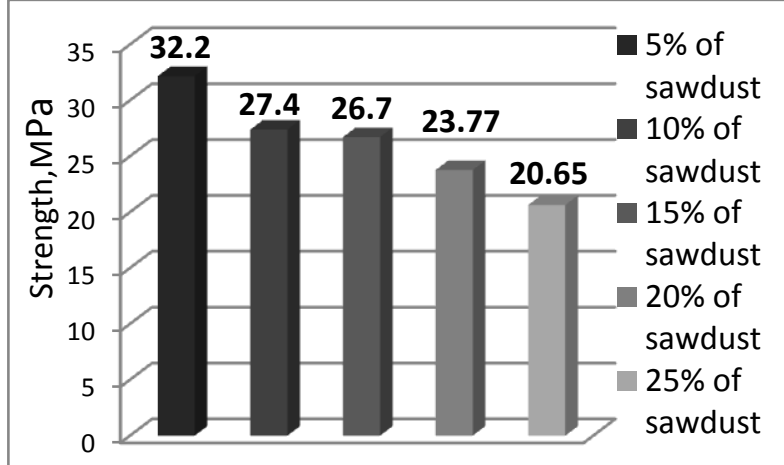

Fig.1. Strength comparison of samples with different amount of sawdust

\subsection{Results}

The Fig. 1 shows that with increasing amount of sawdust the compressive strength was decreasing.The highest strength had the samles with the smallest quantity of sawdust, scilicet $5 \%$. Than the strength was gradually decreacing and finally the smallest strength had the samples with the biggest amount of sawdust $-25 \%$

\section{CONCLUSION}

The experiment showed that sawdust can be used as one of the possible fillers to alkali-aktivated materials based on fly ash. However it also showed that growing quantity of sawdust decreases the compressive strength of the samples. In the nearest future will be studied other properties of these composites such as bending tensile strength, heat conduction, heat capacity, fire resistance, deformations under the temperature in order to check the possibility of their usage as fire-resistant and heat insulating materials. Deeper researches will allow to make conclusions about optimal quantity of sawdust in composites and possibilities of their usage.

\section{REFERENCES}

Barborak, O.; Cervenansky, J.; Bozek, P.; Mihok, J.; Rybansky, R. \& Tothova, M. (2008) Numeric expression of the quality of production technology. In: Annals of DAAAM and Proceedings of DAAAM Symposium, Vol. 19, No.1, ISSN 1726-9679

Benes, L.; Perna, I.; Hanzlicek, J. \& Minar, L. (2007). Alkaliactivated materials - charakteristics, mechanism of chemical reactions and aplication possibilities, Proceeding of Conference TechMat - Perspective Technologies and Materials for Technical Aplications, 15.11.2007, Svitavy, ISBN 978-80-7395-013-2, pp. 185 - 192

Bozek, P. (2008). Robot-operated testing system assigned for testing in laboratory conditions, 1. ed., Tripsoft, ISBN 978 80-89291-19-9, Trnava, pg. 80

Bozek, P. (2009). Supervision and testing robotization of mechanical system's operational reliability, 1. ed., AlumniPress, ISBN 978-80-8096-092-6, Trnava, pg.72

Davidovits, J. (2008). Geopolymer Chemistry and Applications, Geopolymer Institute, ISBN 2-9514-8201-9, Saint-Quentin

Feret, R. (1939). Slags for the manufacture of cement. Rev. Mater. Constr. Trav. Publ. Glukhovsky, V. (1959). Soil silicates, Gostroiizdat, Kiev

Holler, H.; Wirsching, U. \& Pernklau, E. (1983). Experiments on the hydrothermal formation of zeolites from Flyash. Fortschritte der Mineralogie, vol. 61, no. 1, 1983 pp. 92-93

Minar, L.; Benes, L. \& Halas, O. (2010). Summary of energy industry products selected properties of alkali-activated materials and alkali effects on these materials, Proceeding of 27th International Colloquim: „Advanced Manufacturing and Repair Technologies in Vehicle Industry", 19-21.05.2010, Lagow, ISSN 1425-1655, pp. 343-348

Minar, L.; Benes, L. \& Halas, O. (2010). Alkali, water and fluidity effect on mechanical properties of alkali-activated materials on base fly ash. In: Research methods improvement, Borkowski, S. \& Jasinski, J., (Ed.), pp. 123 133, ISBN 978-966-1507-31-8, Dnipropetrovsk

Olsen, N. (1934) Verfahren zum Haerten von Ton bei niedriger Temperatur. Deutsches Reich Patentschrift, 600327, 1934-05-28

Pacheco-Torgal, F.; Castro-Gomes, J. P. \& Jalali, S. (2005). Geopolymeric binder using tungsten mine waste preliminary investigation. In Geopolymer, green chemistry and sustainable development solutions: proceedings of the World Congress Geopolymer 2005, 2005, ISBN 2-95148200-0, pp. 93-98

Palomo, A.; Grutzeck, M. \& Blanco, M. (1999). Alkaliactivated fly ashes A cement for the future. Cement and Concrete Research, vol. 29, pp. 1323-1329

Purdon, A. (1940). The action of alkalis on blast furnace slag. Journal of the Society of Chemical Industry, vol. 59, pp. 191-202

Skvara, F. (2009). Alkali-activated materials - geopolymers, Available from: http://www.vscht.cz/sil/pojiva/publikace.html Accessed: 2009-06-26

Straka, P.; Hanzlicek, T. \& Perna, I. (2007). Properties of alkali activated materials suitable for normalized test. Proceedings of 2007-International Conference Alkali Activated Materials - Research, Production and Utilization, 2007, Prague, ISBN 978-80-214-3642-8, pp. 653-658. Agentura Action M, Prague

Van Jaarsveld, J. G. S.; van Deventer, J. S. J. \& Lukey, G. C. (2002). The effect of composition and temperature on the properties of fly ash and kaolinite-based geopolymers. Chem. Eng. J., vol. 89, pp. 63-73 